\title{
STRATEGI INDUSTRI KREATIF PADA USAHA MIKRO, KECIL, DAN MENENGAH (UMKM) DALAM RANGKA MENJAWAB TANTANGAN MASAYARAKAT EKONOMI ASEAN (MEA)
}

\author{
Sulastri Rini Rindrayani \\ Email: rrindrayani@yahoo.com \\ STKIP PGRI Tulungagung
}

\begin{abstract}
ABSTRAKSI
Pengembangan industri kreatif pada UMKM sangat penting dilakukan karena mempunyai peran besar dalam pembagunan ekonomi terbukti memberikan kontribusi cukup besar dalam PDB dan mampu mengatasi pengaguran. Strategi industri kreatif UMKM dalam rangka tantangan Masyarakat Ekonomi Asean (MEA) dapat dilakukan melalui : (1) SDM sebagai modal dasar, (2) industri, (3) teknologi, (4) Sumber daya, (5) institusi, dan (6) lembaga keuangan. Selain itu dipayungi oleh hubungan yang baik saling menunjang dan bersimboisis mutualisme antara cendikiawan (intellectuals), bisnis dan pemerintah. Dengan Straregi ini diharapkan produk industri UMKM mampu bersaing dalam pasar global khususnya ASEAN.
\end{abstract}

Kata Kunci: Industri Kreatif, UMKM, dan MEA

\section{PENDAHULUAN}

Saat ini kita sudah memasuki MEA yang mulai berlaku sejak akhir tahun 2015. Praheaty (2014) menjelaskan "Tujuan dibetuknya komunitas ASEAN adalah 1) Mempercepat pertumbuhan ekonomi, 2) Meningkatkan perdamaian dan stabilitas regional, 3) Menciptakan dan meningkat-kan kerjasama yang aktif, 4) Memajukan pengkajian mengenai Asia Tenggara, 5) Memelihara kerjasama antar Negara. Sealin itu tujuan lainnya adalah mempermudah peredaran barang dan jasa di seluruh kawasan ASEAN tanpa adanya system bea masuk dan barrier yang selama ini menjadi halangan dalam bekerja sama".

AEC memiliki lima (5) pilar utama, yakni: 1) Aliran bebas barang (free flow of goods), 2) Aliran bebas jasa (free flow of sevice), 3). Aliran bebas investasi (free flof of investment), 4). Aliran bebas tenaga kerja terampil (free flow of skilled labour), 5) Aliran bebas modal (free flow of capita) ( Policy Paper No. 15. 2011).

Dengan demikian dengan adanya MEA akan berdampak positif memudahkan masuknya barang, jasa, investesi, tenaga kerja dan capital dari luar negeri ke dalam negeri atau sebaliknya. Selain itu juga akan berdampak negatif yaitu adanya persaingan atar negara-nenara ASEAN baik pada barang, jasa, investasi, tenaga kerja dan capital. Barang dan jasa yang mempunyai keunggulan kompetetif di pasar ASEAN yang dapat laku di pasar ASEAN, sedang barang dan jasa yang tidak mampu bersaing akan tidak laku di pasar ASEAN. 
AEC Blueprint merupakan sebuah panduan yang digunakan negara-negara ASEAN dalam rangka mencapai AEC 2015, dimana dari semua negara-negara yang tergabung dalam ASEAN mempunyai kewajiban untuk melaksanakan komitmen yang ada pada Blueprint. Dimana AEC Blueprint memuat empat pilar sebagai panduanya, yaitu: ASEAN sebagai pasar tunggal, ASEAN sebagai kawasan dengan daya saing yang tinggi, ASEAN sebagai kawasan dengan pengembangan ekonomi yang merata dengan pengembangan usaha kecil menengah, dan yang terakhir yaitu ASEAN sebagai kawasan yang terintegrasi secara penuh dengan perekonomian global melalui elemen koheren dalam hubungan ekonomi luar kawasan dan meningkatkan peran serta dalam produksi global. ( Anis dan Widisar, 2015: 72)

Penjelas tersebut dapat diartikan bahwa antar negara ASEAN sudah sepakat adanya satu pasar tunggal ASEAN, termasuk Indonesia sebagai salah satu anggota ASEAN. Hal tersebut menjadi tantangan baru dalam perekonomian Negara-negara berkembang salah satunya adalah Indonesia. Kondisi ini juga menuntut para pelaku usaha (UMKM) untuk terus memajukan usaha nya dan bersaing dengan pengusaha lain tidak hanya pengusaha dari Negara sendiri tetapi dari Negara asing.
Departemen Perdagangan (2008: 7) menjelaskan "Berdasarkan studi pemetaan industri kreatif, kontribusi industri kreatif terhadap perekonomian Indonesia dapat dibedakan menjadi 5 indikator utama, yaitu berdasarkan ; 1) Produk Domestik Bruto, 2) kenaga kerjaan, 3) jumlah perusahaan, 4) eksport, dan 5) dampak terhadap sektor lain". Berdasarkan indikator tesebut menujukkan bahwa, Menteri Perindustrian Saleh Husin menyatakan, pada tahun 2015-2019 mendatang kontribusi Produk Domestik Bruto (PDB) ekonomi kreatif ditargetkan mencapai 7-7,5\% dengan syarat pertumbuhan PDB Industri Kreatif minimal 5-6\%. Selain itu, tingkat partisipasi tenaga kerja industri kreatif juga ditargetkan mencapai 10,5-11\% dari total tenaga kerja nasional, dan peningkatan devisa negara mencapai 6,5\%-8\% (Hartono,2015).

Pertumbuhan produksi menurut data BPS pada tahun 2015 5,71\% lebih rendah dari pada tahun 2014 sebesar 7,51\%. Data tersebut meyakinkan bahwa industri kreatif berperan besar dalam mempercepat pertumbuhan pembangunan ekonomi. Industri kreatif tidak hanya memberikan kontribusi terhadap pertumbuhan ekonomi, tetapi dapat menciptakan iklim bisnis yang positif, dapat memperkuat citra dan identitas bangsa Indonesia, mendukung pemanfaatan sumberdaya yang terbarukan, merupakan pusat penciptaan inovasi dan pembentukan 
kreativitas, dan memiliki dampak sosial yang positif.

Namun demikian Industri mikro, kecil,dan menengah yang ada pada masyarakat Indonesia mayoritas masih mengunakan usaha sistem tradisional artinya para pelaku usaha belum terlalu memeperhatikan tingkat efisiensi dan efektifitas dari usaha yang dijalankannya. Hal ini yang salah satunya akan menjadi ancaman bagi Indonesia dalam upayanya bersaing kedalam masyarakat ekonomi ASEAN, sehingga persaingan antar pelaku usaha akan minim kreativitas dan inovasi. Oleh karena perlu meningkatkan kulitas industri kreatif baik dari segi 1) SDM sebagai modal dasar, (2) industri, (3) teknologi, (4) Sumber daya, (5) institusi, dan (6) lembaga keuangan. Di samping itu cendikiawan (intellecttuals), bisnis dan peran pemerintah sangat diperlukan untuk mendukung dan mengkembangkan insudri kreatif pada UMKM.

\section{PEMBAHASAN}

\section{a. Ekonomi kreatif dan Industri Kreatif}

Ekonomi kreatif sebenarnya adalah wujud dari upaya mencari pembangunan yang berkelanjutan melalui kreativitas, yang mana pembangunan yang berkelanjutan adalah suatu iklim perekonomian yang berdaya saing dan memiliki sumber daya yang terbarukan. Dengan kata lain ekonomi kreatif adalah manifestasi dari semangat bertahan hidup yang sangat penting bagi negara-negara maju dan juga menawarkan peluang yang sama untuk negara-negara berkembang. Pesan besar yang ditawarkan oleh ekonomi kreatif adalah pemanfaatan sumberdaya yang bukan hanya terbarukan, bahkan tak terbatas, yaitu ide, talenta dan kreativitas (Pagestu , 2008: 1).

Ekonomi kreatif merupakan gelombang ekonomi baru yang lahir ada awal abad ke-21. Gelombang ekonomi baru ini mengutamakan intelektual sebagai kekayaan yang dapat menciptakan uang, kesempatan kerja, pendapatan, dan kesejahteraan. Inti dari ekonomi kreatif teretak pada indusri kreatif, yaitu Industi yang digerakkan oleh para kreator dan inovator. Rahasia eonomi kreatif terletak pada kreativitas dan keinovasian.

Industri kreatif menurut Departemen perdagangan (2008: 4) "industri yang berasal dari pemanfaatan kreatifitas, ketrampilan, serta bakat individu untuk menciptakan kesejahteraan serta lapangan pekerjaan melalui penciptaan dan pemanfaatan daya kreasi dan daya cipta individu tersebut". Jadi industri kreatif lebih menekankan pada pemfaatan kretifitas, inovasi, dan ketrampilan yang dimiliki seseorang dalam menghasilkan suatu ide, gagasan, ataupun produk. Dengan demikian industri kreatif akan berkembang bila pencipta mempunyai 
kreativitas dan inovasi pada ide, gagasan dan produk yang dihasilkan.

Sub sektor industri berbasis kreatif adalah 1) periklanan, 2) asitektur, 3) pasar barang seni, 4) kerajinan, 5) desain, 6) fesyen, 7) video, film, dan fotografi, 8) permainan interaktif, 9) musik, 10) seni pertunjukan, 11) penerbitan dan percetakan, 12) layanan kompter dan piranti lunak, 13) televisi dan radio, dan riset dan pengembangan (Departemen Perdagangan, 2008:6).

\section{b. Permasalahan Utama Industri Kreatif}

Ada lima permasalahan utama yang menjadi pokok perhatian dalam rencana pengembangan industri kreatif untuk pencapaian tahun 2015, anatar lain:

1) Kualitas dan kuantitas sumberdaya insan sebagai pelaku dalam industri kreatif, yang membutuhkan perbaikan dan pengembangan lembaga penddikan dan pelatihan, serta pendidikan bagi insane kreatif Indonesia.

2) Iklim kondusif untuk memulai dan menjalankan usaha di industri kreatif, yang meliputi sistim administrasi negara, kebijakan dan peraturan, infrastruktus yang diharapkan data dibuat kondosif bagi perkembangan industri kreatif.

3) Penghargaan/aprsiasi terhadap insan kreatif Indonesia, dan karya kreatif yang dihasilkan, yang terutama berperan untuk menumbuhkan rangsangan berkarya bagi insan kreatif Indonesia dalam bentuk dukungan financial maupun non finansial.

4) Mempercepat tumbuhnya teknologi informasi dan komunikasi, yang sangat erat kaitanya dengan perkembangan akses bagi masyarakat untuk mendapatkan informasi, bertukar pengetahuan dan pengalaman, sekaligus akses pasar kesemuannya yang sangat penting bagi pengembangan industri kreatif.

5) Lembaga pembiayaan yag mendukung pelaku industri kreatif, mengingat lemahnya dukungan pembiayaan konvensional dan masih sulit akses bagi enterepreneur kreatif untuk mendapatkan sumber dana alternative model ventura, atau dana coporate sosial responsibility (CSR) (Departemen Perdagangan, 2008: viii)

Kelima pesalahan tersebut di atas perlu diatasi dengan baik, sehingga industri kreatif dapat berkembang sesuai tujuan yang diharapkan.

\section{c. Strategi Industri Kreatif UMKM dalam Menghadapi MEA}

Model strategi industri kreatif pada UMKM dapat memperkuat perekonomian Indonesia.

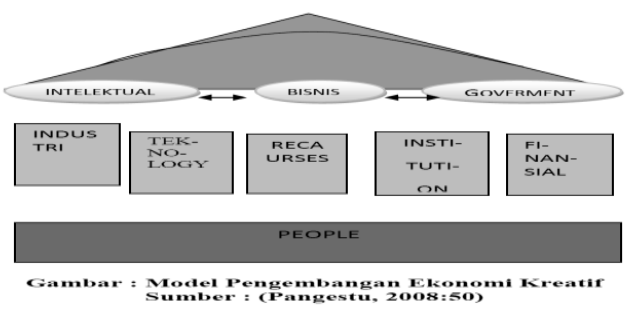




\section{d. Meningkatkan ketrampilan dan kreativitas Sumberdaya manusia}

Berdasarkan gambar di atas dapat dijelaskan langkah pertama dalam pengembangan industri kreatif adalah peningkatan ketrampilan dan kreativitas SDM. Pondasi industri kreatif adalah sumberdaya insan (people), yang merupakan elemen terpenting dalam industri kreatif. Hampir seluruh sektor industri, sumberdaya merupakan peran utama dalam industri kreatif, dibandingna dengan faktor-faktor produksi lainya. Oleh karena itu, pembangunan industri kreatif Indonesia yang kompetitip harus dilandasi dengan pembagunan SDM yang terampil, terlatih dan terberdayakan untuk menumbuhkembangkan pengetahuan dan kreativitas. Pengetahuan dan kreativitas inilah yang menjadi faktor produksi utama di dalam industri kreatif.

Demikian juga dalam UMKM, SDM merupakan faktor produksi utama dalam menumbuhkembangkan industri kretaif, SDM yang mempunyai ketrampilan dan pengetahuan sehingga akan mampu untuk berpikir kreatif dan inovatif. Penciptaan SDM yang mempunyai ketrampilan dan kreativitas dalan industri tertentu tidak mudah, karena pengetahuan, ketrampilan dan kreativitas perlu dilakukan melalui pendidikan dan pelatihan. Dalam pendidikan formal peran kurikulum penting dalam melahirkan anak bangsa yang mempunyai jiwa entrepreneurship dan kreativitas. Oleh karenanya desain kurikulum lebih menekankan pada kompetensi dan kreativitas outnya. Selain itu peran pendidikan non formal (keluarga) merupakan pendidikan awal yang dialami pengusaha, maka peran orang tua sangat penting dalam menanamkan jiwa wirausaha pada putra-putrinya.

\section{e. Industri}

Industri merupakan salah satu pilar /tiang yang dapat mengembangan indusri kreatif pada UMKM. "Industri merupakan bagian dari kegiatan masyarakat terkait dengan produksi, distribusi, pertukaran serta konsumsi produk atau jasa dari sebuah negara atau area tertentu". (Pangestu, 2008: 52). Dalam keguatan usaha industri kreatif yang perlu dipikirkan adalah rantai nilai industri kreatif. Rantai nilai yang dimaksudkan adalah“ proses menciptakan nilai yang umumnya terjadi di industri kreatif" (Pangestu, 2008: 69). Proses rantai nilai ada empat tahap, yaitu (1) kreasi, (2) produksi, (3) distribusi, dan (4) komersial.

Daya kreasi merupakan faktor input dalam industri kreatif, termasuk di dalamnya cara mendapatkan input, mengolahnya, dan menyimpannya. Oleh karenanya produsen harus mempunyai ketrampilan, daya kreativitas, bakat, dan orisional ide dalam meghasilkan produk. Produk yang unik, berbeda, orisinil, mampu berkompetisi dengan produk lawannya dan berpotensi menciptakan 
lapangan kerja serta kemakmuran bagi pemiliknya.

Produksi adalah segala aktifitas untuk mengolah input menjadi output berupa barang atau jasa. Aktivitas proses produksi bisa replekasi, reproduksi, dan produk baru. Pada produksi ini yang perlu dipikirkan efesiensi dan kreativitas sehingga produk berbeda dengan produk lawannya dan tetap mampu bersaing. Distribusi merupakan kegiatan menyimpan dan mendistribusikan output. Pemilihan sistem distribusi perlu dipikirkan, misalnya melalui negosiasi hak distribusi. Misal negosiasi untuk produk-produk industri kreati yang maya, misal lagu dan perangkat lunak dapat dikirim melalui email. Komersialisasi segala aktivitas yang berfungsi memberikan pengetahuan tentang produk dan layanan yang disediakan, dan juga mempengaruhi konsumen untuk membelinya (Pangestu, 2008: 73). Misalnya pemasaran mempunyai fungsi pencitraan, targeting, dan positioning. Penjualan menggunakan agen, distributor, lisensi. Promosi bisa melalui pameran. Expo, pertunjukkan, esplorasi kena media baru.

\section{f. Teknologi}

Teknologi bukan hanya mesin ataupun alat bantu yang sifatnya terwujud, tetapi teknologi ini termasuk kumpulan teknik atau metode-metode, atau aktivitas yang membentuk atau yang mengubah budaya" (Pangestu, 2008: 52), artinya teknologi dalam industri kreatif adalah segala sesuatu yang dapat digunakan untuk menghasilkan barang atau jasa baik berupa alat, metode ataupun teknik. Teknologi ini akan menghasilkan aktivitas individu dalam karya nyata.

Dukungan dan jenis teknologi terhadap industri kreatif sangat tergantung pada intensitas sumberdaya serta substansi dominan dalam industri tersebut.Artinya bahwa kemampuan dalam mengaplikasikan teknologi sangat tergantung dengan tingkat pendidikan, pengetahuan, dan ketrampilan dalam mengusai teknologi tersebut. Misal Indonesia hanya mampu menerapkan teknologi madya. Berkait hal tersebut peran pendidikan dalam penguasaan pengetahuan dan teknologi sangat dibutuhkan. Hampir subsektor industri kreatif ini membutuhkan teknologi informasi sebagai teknologi mendukung dalam proses kreasi, produksi, distribusi ataupun komersialisasi. Oleh karena itu ICT (Imformation \& Communication Technology) merupakan infrastruktur yang vital bagi pengembangan ekonomi kreatif. Pada rantai kreasi ICT dipergunakan untuk memperoleh, menyebarkan dan melakukan pertukaran informasi dan memperkaya ide kreasi. Pada rantai distribusi dan komersialisasi ICT dibutuhkan dalam proses transaksi dan promosi.

Subsektor industri kreatif yang dominan ICT adalah film, video, fotografi, 
musik, TV dan radio, periklanan, penerbitan dan percetakan, arsitktur, desain, music, riset dan pengembangan, dan permainan interaktif. Sedangkan subsektor industri kreatif yang lebih dominan seni budaya dan sumber daya adalah fesyen, dan kerajinan. Pemilihan dan penggunaan teknologi dalam industri kreatif sangat menentukan kuantitas dan kualitas dari produk yang dihasilkan

\section{g. Resources}

Pilar resources adalah input yang dibutuhkan dalam proses menciptakan nilai tambah, selain idea, dan kreativitas yang dimiliki oleh sumber daya tersebut. Sumber daya meliputi sumber daya alam maupun kesediaan lahan yang menjadi input penunjang industri kreatif. Pemanfaat sumber daya alam yang tersedia diakukan secara optimal tetapi harus diikuti pola pikir ranah lingkungan. tentunya dalam pemanfaat sumber daya alam akan bisa optimal maka perlu pengetahuan, ketrampilan, dan kreativitas yang dapat memberikan nilai tambah pada dari sebelumnya, misal rotan, merupakan sumberdaya unik di Indonesia, dapat dibuat produk-produk fisikal seperti desain, krajinan dan fesyen memberikan identitas nasional yang dibutuhkan dalam berkompetisi di pasar global.

Bila melihat dari rantai nilainya khususnya yang berkaitan degan produksi, tidak seluruh subsector industri kreatif membutuhkan sumberdaya, khususnya sumber daya alam. Subsektor yang membutuhkan sumber daya alam antara lain kerajinan, fesyen, percetakan dan penerbitan, serata riset dan pengembangan teknologi. Sumber daya alam Indonesia berlimpah tetapi belum bisa diolah secara maksimal. Selain berlimpah sumber daya alam Indonesia mempunyai keragaman yang dapat dijadikan kekuatan bangsa Indonesia karena tidak dimiliki oleh negara lain. Keragaman sumberdaya ala mini dapat dijadikan senbagai bahan baku untuk menghasilkan produk industri kreatif.

\section{h. Institusi}

Pilar institusi ini dimaksudkan kondisi dimana masyarakat mau menerima perbedaan/toleransi, mengapreasi sejarah, budaya serta warisan budaya Indonesia, meskipun berbeda nilai. Misal batik dan kebaya dipakai oleh seluruh masyarakat Indonesia, semula pakaian batik hanya digunakan oleh oran dewasa dan acara tertentu dan kebaya digunakan oleh orang jawa saja. Sasaran penguatan pilar institusi adalah" masyarakat yang berpemikiran terbuka mengkonsumsi produk kreatif lokal" (Pangestu, 2008: 97), hal ini dapat dicapai dengan cara sebagai berikut:

1) Menciptakan penghargaan terhadap hak atas kekayaan intelektual (HKI) dan pengakuan terhadap manfaatnya bagi ekonomi. 
2) Peningkatan apresiasi terhadap budaya bangsa yang diwujudkan dalam penghargaan pada produk bermuatan budaya daerah/nasional yang berkualitas.

3) Meningkatkan kesadaran dan penghargaan dunia internasional terhadap Indonesia dan produk/jasa bermuatan budaya yang membuat ekonomis:

4) Menciptakan masyarakat kreatif yang saling menghargai dan saling bertukar pengetahuan demi kuatnya industri kreatif nasional. (Pangestu,2008:97)

Jadi produk yang dihasilkan oleh UMKM harus dapat menjujung tinggi budaya lokal bangsa Indonesia. Misalnya batik merupakan kerajinan peniggalan warisan budaya dapat dilatihkan kepada generasi muda sehingga produk batik tidak punah dan bisa berkembang dikalangan pemuda sebagai pewaris budaya bangsa.

\section{i. Lembaga pembiayaan (Financial Intermediary)}

Lembaga keuangan mempunyai peran penting dalam pemberian modal industri kreatif pada UMKM. Banyak hasil penelitian membuktikan kesulitan berkembangya UMKM karena sulitnya memperoleh modal melalui lembaga keuangan. Pada pilar ini lembaga-lembaga pembiayaan atau donor percaya terhadap industri kreatif sebagai industri yang menarik untuk berinvestasi. Secara singkat pilar penguatan lembaga pembiayaan adalah,’tercapainya tingkat kepercayaan yang tinggi oleh lembaga keuangan ataupun donor terhadap industri kreatif sebagai industri yang menarik untuk berinvestasi dan terciptanya informasi simetrik antara pelaku usaha dengan lembaga intermediasi" (Pangestu, 2008: 98). Dengan demikian UMKM dalam perkembangannya sangat tergantung dari kemudahan, kecepatan, dan ketepatan lembaga finansial dalam memberikan pinjaman untuk mengembangkan usahanya.

Setiap jenis usaha pada umumnya membutuhkan pembiayaan untuk memulai usahanya atau proses operasionalnya. Ada sebagain industri kreatif yang tidak membutuhkan modal awal yang besar untuk memulia usaha, karena industri kreatif sangat tergantung pada kreativitas individu. Walaupun para pelaku industri kreatif dapat bertahan tanpa adanya pembiayaan, tetapi industri keratif tetap membutuhkan bantuan pembiayaan untuk dapat selalu kreatif dalam menciptakan produk dan jasa baru kepada konsumen. Oleh karena peran lembaga keuangan diperlukan untuk mempercepat pengkembangan industri kreatif, misalnya mempermudah proses peminjaman pada UMKM dengan bunga yang ringan.

\section{j. Kolaborasi antara Intelektual, Bisnis, dan Govermant \\ Pada gambar di atas bangunan} dipayungi oleh hubungan antara intelektual/cendekiawan, bisnis dan pemerintah yang disebut sistem "triple halix". Artinya 
bahwa tumbuhkembangnya industi kreatif pada UMKM dipengaruhi oleh hubungan erat, saling menunjang dan bersimbiosis mutualisme antar ketiga sektor tersebut sehingga industri kreatif akan berdiri kooh dan berkesinambungan. Cendikiawan dalam hal ini adalah budayawan, seniman, punakawan, Begawan, para pendidik dilembaga pendidikan, para pelopor di paguyuban, padepokan, sanggar budaya dan seni, individu atau kelompok studi dan peneliti, penulis dan tokoh-tokoh lainnya di bidang seni yang terkait dengan pengembang industri kreatif. Bisnis disebut juga perusahaan yang menghasilkan barang atau jasa untuk memperoleh keuntungan dan meningkatkan kemakmuran para pemiliknya. Dalam perkembanganya produsen sangat membutuhkan informasi, kerampilan, pengetahuan dari cendikiawan untuk melaksanakan kreativitas dalam menghasilkan barang atau jasa. Misal usaha batik tulis butuh ketrampilan seni lukis.

Untuk mendapatkan hasil yang optimal dalam pengembangan industri kreatif maka perlu kolaborasi atar tiga aktor utama (cendikiawan,bisnis, dan pemerintah), upaya yang dapat dilakukan (Pangestu, 2008: 98).

1) Komitmen cendekiawan, bisnis dan pemerintah, koordinasi aktor secara berkesinambungan, serta mengupayakan sinergi untuk mengembangkan industri kreatif. Komitmen ini meliputi keterlibatan financial dan non financial.

Dalam hal finansial pembiayaan program pengembangan industri kreatif dapat dilakukan melalui APBN, CSR, dan alokasi dana Riset. Sedang non finansial melalui pelaksanaan administrasi public yang lebih cepat dan efisien, komitmetmen pendidik untuk memberi materi sebaik-baiknya.

2) Membentuk knowledge space bagi industri kreatif dengan menciptakan pertukaran informasi, pengetahuan, skill, teknologi, pengalaman, preferensi lokasi pasar, serta informasi lainnya.

Dengan demikian besar kecilnya kolaborasi tiga aktor tersebut dalam berkotmitmen untuk mengembangkan indutri kreatif berpengaruh kepada besar kecilnya perkembangan industri kreatif. Semakin peduli ketihga aktor dalam mengembangkan industri keratif semakin cepat perkembangan industri kreatif pada UMKM baik dari segi kulaitas dan kuantitas.

\section{PENUTUP}

Industri kreatif pada UMKM perlu untuk ditingakatkan baik dari segi kuantitas maupun kualitas, karena terbukti bahwa industri kreatif dapat memberikan kontribusi dalam menyelesaikan permasalahan pembagunan ekonomi, antara lain 1) pada tahun 2015 industri kreatif memberikan kontribusi terhadap pendapat PDB 7.8\% dari seluruh pendapatan 
nasional, 2) dapat menciptakan lapanan krrja sehingga mengurangi pengangguran, 3) dapat meningkatkan perolehan divisa dari ekspor industri kreatif, 4) dapat meningkat pertumbuhan industri lain yang terkait.

Strategi industri kreatif pada UMKM dalam menjawab tantangan MEA dapat dilakukan melalui: peningkatan kualitas SDM, 2) Peningkatan Teknologi, 3) Peningkatan rantai industri, 4) peningkatan pemilihan dan pengolahan sumberdaya alam sebagai bahan penghasil industri kreatif, 5) peningkatan pelayanan dan kemudahan lembaga pembiayaan industri kreatif, 6) memilihara mengkembangkan budaya bangsa yang menunjukkan indentitas bangsa dalam pelaku industri kreatif, dan adayanya dukungan tiga aktor cendikiawan, bisnis, dan pemerintah berkomitmen secara sinergi untuk mendukung dan mengembangkan industri kreatif pada UMKM.

\section{DAFTAR PUSTAKA}

Dwi Ratna Prahasty. 2015. Kesiapan UKM Di Indonesia Untuk Meningkatkan Daya Saing Dan Kualitas Diri Dalam Menghadapi Asean Economic Community (AEC). Ekonomi Kreatif Berkontribusi $7 \%$ ke PDB Indonesia (selasa, 21 Oktober 2014.Website:,ww.kemenperin.go.id / artikel/1318/Menperin:-KontribusiPDB-Ekonomi-Kreatif-Ditargetkan di akses 3 September 2016.
Hartono, 6 oktober 2015, Kontribusi PDB Ekonomi Kreatif Ditargetkan 7,5\%, kepala pusat komunikas, Website: www.kemenperin.go.id, diakses 5 sepember 2016

Pangestu, Meri Ilka, 2008. Pengembangan Ekonomi Kreatif Indonesia 2025. Rencana Pengembangan Ekonomi Kreatif Indonesia 2009-2015. Departemen Perdagangan Republik Indonesia.

Policy Paper No. 15. 2013. Masyarakat Ekonomi ASEAN 2015. Peluang dan Tantangan bagi UMKM Indonesia. https://infoukm.wordpress.com/ di akses 27 Agustus 2016

Widiasari, niken dan Anis, Muchlison 1, Simposium Nasional Teknologi Terapan (SNTT) 2015 , ISSN: 2339-028X, Analisis Kesiapan Industri Kreatif Menghadapi Masyarakat Ekonomi AseaN (MEA) (Studi Kasus Industri Blangkon di Serengan Surakarta) Prodi Teknik Industri, Fakultas Teknik, Universitas Muhammadiyah Surakarta. 